\title{
SCREENING OF FILAMENTOUS FUNGI FOR PRODUCTION OF MYROSINASE
}

\author{
Nuansri Rakariyatham*; Bordin Butrindr; Hataichanoke Niamsup; Lalida Shank \\ Department of Chemistry, Faculty of Science, Chiang Mai University, Chiang Mai, Thailand
}

Submitted: February 18, 2005; Returned to authors for corrections: May 30, 2005; Approved: July 05, 2005

\begin{abstract}
Aspergillus sp. NR46F13, isolated from soil via sinigrin-barium sulphate agar technique, was tested for myrosinase production. The fungus degraded glucosinate and produced $3.19 \mathrm{U} \mathrm{mL}^{-1}$ of myrosinase after $48 \mathrm{~h}$ cultivation. due to the high myrosinase production, this new isolate is a potential candidate for industrial applications.
\end{abstract}

Key words: myrosinase, Aspergillus sp., sinigrin, glucosinolate, allylisothiocyanate

\section{INTRODUCTION}

Glucosinolates are amino acid derived from natural plant products containing thioglucose and sulfate moieties. They are found in Brassicales, mainly in Brassicaceae (Cruciferae), and in several other families of dicotyledonous angiosperms. Upon tissue disruption, glucosinolates are hydrolyzed by myrosinase ( $\beta$-thioglucoside glucohydrolase EC 3.2.3.1), to unstable intermediates that, as dictated by chemical conditions, spontaneously rearrange to isothiocyanates, thiocyanates or nitriles $(1,8)$. Glucosinolate breakdown products are proposed to act as allelochemicals and play a role in plant defenses against herbivores, pets and pathogens $(1,8)$. As components of food for humans and feed for livestock, the biological activities of glucosinolate hydrolysis products have generated considerable toxicological and pharmacological interest. Natural isothiocyanates derived from aromatic and aliphatic glucosinolates are effective chemoprotective agents that block chemical carcinogenesis and prevent several types of cancer in rodent model (13).

Myrosinase and glucosinolates have been studied extensively. Many reports have described the isolation and characterization of myrosinase, especially from mustard and oilseed rape. A significant effort has been put into the recent cloning of plant myrosinase genes (2). Myrosinase was not only found in plants but also in microorganisms. Over the past 40 years a number of microorganisms including bacteria and fungi have been reported for their glucosinolatedegradation properties. Most works have been concentrated on characterization of glucosinolate degradation by intact microbial cells $(3,6,9,12)$ and several reports described the selection of Aspergillus sp. for myrosinase production $(4,10,12)$. The study of myrosinase, therefore, is significant for both biological and biotechnological aspects of food and feed industries.

Our research unit has been interested in studying myrosinase from Aspergillus sp. in many aspects including biodegradation in liquid and solid cultures $(9,10)$. A new technique for detection of microorganisms that produces myrosinase, using sinigrinbarium agar plates, was developed (11). To our knowledge no investigation has been carried out on screening of microorganisms for improved myrosinase production.

In this paper, we describe the screening and characterization of a new isolate for myrosinase production.

\section{MATERIALS AND METHODS}

One hundred fifty soil samples, potentially containing glucosinolate-degrading microorganisms, were collected from Lamphun province, Thailand. Soil samples were bottled in sterile vials. One gram of each sample was suspended in $10 \mathrm{~mL}$ sterile distilled water. After shaking at room temperature $\left(25^{\circ} \mathrm{C}\right)$, the samples were let to settle at room temperature for $2-3 \mathrm{hr}$. Then,

*Corresponding Author. Mailing address: Department of Chemistry, Faculty of Science, Chiang Mai University, Chiang Mai, 50200, Thailand. Fax: (+6653) 892277. E-mail: nuansri1@yahoo.com 
$100 \mu \mathrm{L}$ of the supernatant was spread onto nutrient agar $(2 \mathrm{~g}$ beef extract, $2 \mathrm{~g}$ tryptone and $1.5 \mathrm{~g}$ agar in $100 \mathrm{~mL}$ distilled water) and potato dextrose agar ( $3.9 \mathrm{~g}$ potato dextrose agar in $100 \mathrm{~mL}$ distilled water) plates.

Re-plating was made until pure cultures were obtained. The selected strains were inoculated onto sinigrin-barium agar plates (11), arid incubated at $30^{\circ} \mathrm{C}$. Growth was observed daily, and the strains that grew on sinigrin-barium agar plates were re-plated onto mustard extract agar (10). Incubation was carried out at $30^{\circ} \mathrm{C}$. The plates were observed daily. Each distinct growing colony was picked and then plated onto nutrient agar or potato dextrose agar plates.

Myrosinase production by the selected strains was tested in mustard extract medium in different conditions of $\mathrm{pH}$, incubation time and incubation temperature.

An innoculum, prepared from 1-week-old culture having a concentration of $10^{6}$ spores $\mathrm{mL}^{-1}$, was transfered to eighteen $125 \mathrm{~mL}$ Erlenmeyer flasks containing $25 \mathrm{~mL}$ mustard extract medium with different $\mathrm{pH}$ values $(10 \mathrm{mM}$ glucosinolates in 0.1 $\mathrm{M}$ sodium phosphate buffer). Incubation was carried out at $30^{\circ} \mathrm{C}$ in a water-bath, shaken at $150 \mathrm{rev} \mathrm{min}^{-1}$. At each time point, a two mycelial samples were harvested and washed. One mycelial sample was used for determination of fungal cell dry weight by washing and drying at $105^{\circ} \mathrm{C}$. A culture filtrate of the other sample was assayed for glucose and glucosinolates contents while fungal cell pellet was disrupted using a mortar. Cell-free extract obtained after centrifugation $\left(12,000 \mathrm{x} \mathrm{g}, 25 \mathrm{~min}, 4^{\circ} \mathrm{C}\right)$ was assayed for myrosinase activity. The effect of incubation temperature on myrosinase production was studied at 28 to $40^{\circ} \mathrm{C}$. The myrosinase assay was done according to Sakorn et al., 1999. Protein was determined according to Petroski and Kwolek, 1985. One unit of myrosinase activity was defined as the amount of enzyme that catalyzed the liberation $1 \mu \mathrm{mol}$ of glucose per minute from sinigrin under the above described conditions.

\section{RESULTS AND DISCUSSION}

One hundred fifty soil samples suspected to contain myrosinase-producing microorganisms were collected. One hundred sixty one microorganisms were isolated and tested for myrosinase production. The screening result showed 28 newly isolated strains with positive opaque zone on sinigrin-barium sulphate agar. Myrosinase activity was found in all positive Aspergillus sp. that grew on sinigrin barium sulphate agar.

In this study, most selected strains degraded all glucosinolate in the first $36 \mathrm{~h}$ growth period, with more than half of glucosinolate degraded within $18 \mathrm{hr}$ of growth (Fig. 1). On the other hand, Aspergillus sp. NR46F4, NR46F13 and NR46F14 did not completely degrade glucosinolate within the same growth period.

Growth on mustard extracted media was investigated in all selected strains. Aspergilllus sp. grown on mustard extracted medium with no supplement presented relatively high intracellular myrosinase activity. Maximum myrosinase production varied from 3.19 to $1.25 \mathrm{U} \mathrm{mL}^{-1}$, and was higher when to previous reported results: Aspergillus syndowi IFO4284 (0.08 $\left.\mathrm{U} \mathrm{mL}^{-1}\right)$ (5), Aspergillus niger AKU3302 (0.088 U mL $\left.\mathrm{mL}^{-1}\right)(4)$, Aspergillus syndowi $\mathrm{QW} 31 \mathrm{c}\left(0.096 \mathrm{U} \mathrm{mL}^{-1}\right)(7)$ and Aspergillus sp. NR-4201 (0.28 U mL $\left.\mathrm{mL}^{-1}\right)$ (10). Aspergillus sp. NR46F13 presented the highest myrosinase activity $\left(3.19 \mathrm{U} \mathrm{mL}^{-1}\right)$, and cell dry weight $\left(15.67 \mathrm{mg} \mathrm{mL}^{-1}\right)$ within $48 \mathrm{hr}$ of glucosinolate degradation. The highest myrosinase production and the highest fermentation parameters did not coincide with rapid glucosinolate consumption.

Optimal conditions for myrosinase production were different

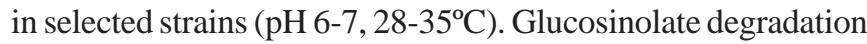
rate was higher than that reported in previous works for Aspergillus sp NR-4201 (9,10) and Aspergillus calvatus (12). The new isolate of Aspergillus sp. presented higher myrosinase production than that reported in previous studies.

Table 1. Optimal conditions for myrosinase production.

\begin{tabular}{lccccc}
\hline Organism & $\mathrm{CDW}^{*}(\mathrm{mg} / \mathrm{ml})$ & $\begin{array}{c}\text { Glucosinolate } \\
\text { degradation }(\mathrm{h})\end{array}$ & $\begin{array}{c}\text { Temperature }(\mathrm{C}) \\
\mathrm{pH}\end{array}$ & $\begin{array}{c}\text { Myrosinase } \\
\text { activity }(\mathrm{U} / \mathrm{ml})\end{array}$ \\
\hline Aspergillus sp. NR463 & 6.09 & 36 & 30 & 6.5 & 1.35 \\
Aspergillus sp. NR465 & 12.5 & 30 & 30 & 7.5 & 1.51 \\
Aspergillus sp. NR468 & 8.36 & 30 & 30 & 7.5 & 2.41 \\
Aspergillus sp. NR4617 & 11.05 & 36 & 30 & 6.5 & 1.25 \\
Aspergillus sp. NR4621 & 18.06 & 30 & 30 & 7.5 & 1.44 \\
Aspergillus sp. NR46F4 & 16.35 & 48 & 35 & 6.5 & 3.65 \\
Aspergillus sp. NR46F13 & 15.67 & 48 & 30 & 6.5 & 2.82 \\
Aspergillus sp. NR46F14 & 16.05 & 48 & & \\
\hline
\end{tabular}

*CDW: Cell dry weight. 


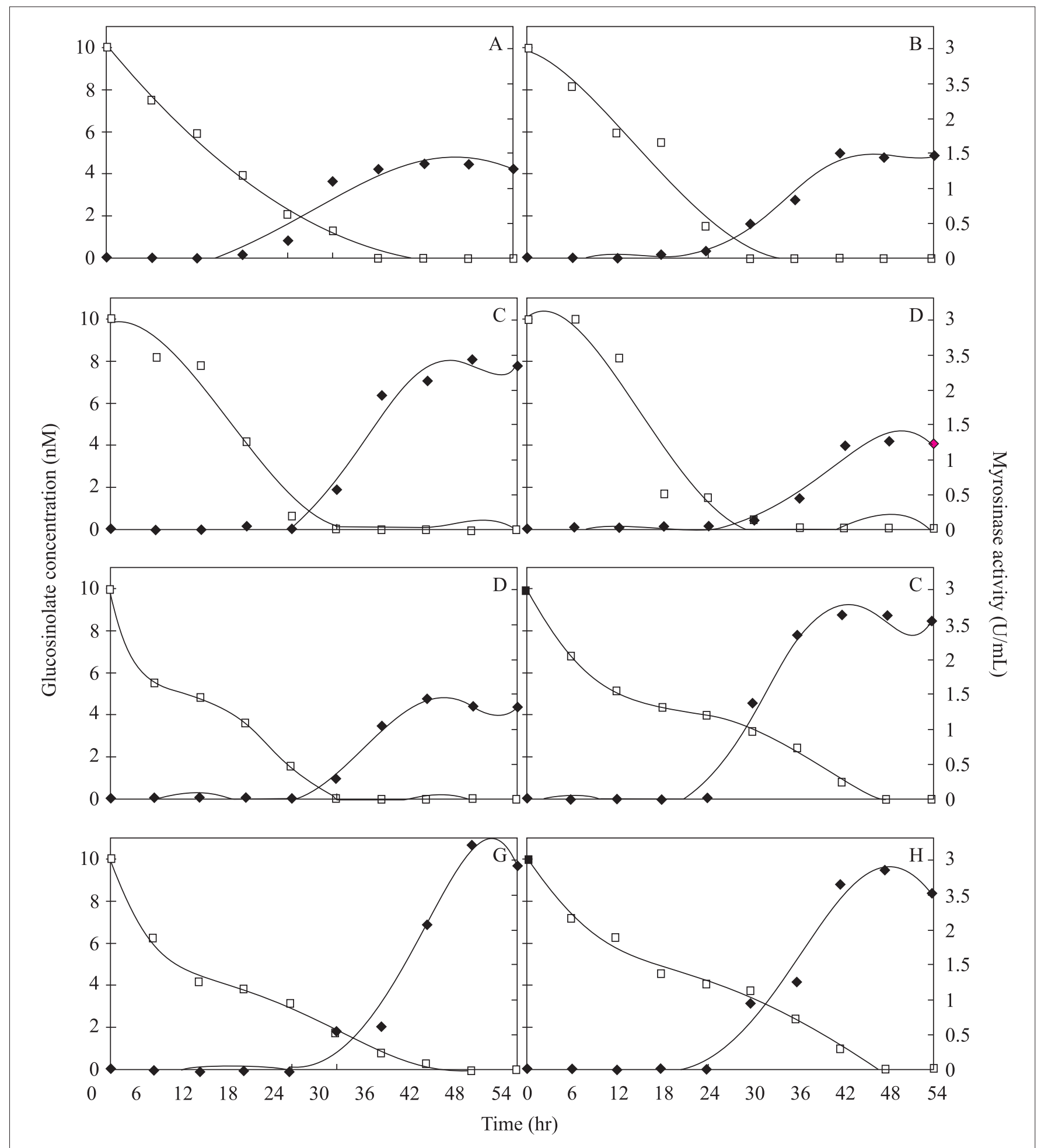

Figure 1. Glucosinolate degradation ( $\square$ ) and myrosinase production ( $\mathbf{\square})$ by Aspergillus sp. NR463 (A), Aspergillus sp. NR465 (B), Aspergillus sp. NR468 (C), Aspergillus sp. NR4617 (D), Aspergillus sp. NR4621 (E), Aspergillus sp. NR46F4 (F), Aspergillus sp. NR46F13 (G) and Aspergillus sp. NR46F14 (H) grown in batch culture using mustard extract media for $54 \mathrm{~h}$ at optimal conditions shown in Table 1. 
A microorganism that presents high myrosinase activity a relatively short time would be more effective for process optimization on an industrial scale, since such organism requires less energy and is less likely to be contaminated. Some of the filamentous fungi tested presented maximum myrosinase activity in 30 to $36 \mathrm{~h}$, however this production was relatively low (Fig. 1). For other strains, (NR46F4, NR46F13 and NR46F14) a long growth period was required for total glucosinolate degradation. Myrosinase production for those strains occurred at $42 \mathrm{hr}$.

We hereby introduce new myrosinase-overproducing microorganisms, characterized by high levels of enzymatic activity, that also possess ability to grow in the low cost medium. Considering the potential application of these fungi in degradation of glucosinolate-rich wastes from agro industry, and the possibility of producing valuable glucosinolate derived products, further studies are certainly warranted.

In conclusion, a newly isolated myrosinase-overproducing Aspergillus sp. newly has been obtained and characterized as a good enzyme producer, with valuable hydrolysis products. This myrosinase enzyme offers a great potential for industrial applications, such as feed detoxification and enhanced yield of flavor industrial production (allylisothiocyanate production).

\section{ACKNOWLEDGEMENTS}

The authors wish to thank the Department of Chemistry, Faculty of Science, Chiang Mai University. This research was financially supported by the Thailand Research Fund (TRF).

\section{RESUMO}

\section{Seleção de fungos filamentosos para a produção do mirosinase}

A linhagem Aspergillus sp. NR46FB, isolada de solo através da técnica do ágar sulfato de bário-sinigrina, foi testada quanto à produção de mirosinase. $\mathrm{O}$ fungo degradou completamente $\mathrm{o}$ glicosinolato e produziu 3,19 U.mL $\mathrm{mL}^{-1}$ de mirosinase, após $48 \mathrm{~h}$ de cultivo. Devido à alta produção de mirosinase, esse novo isolado é um potente candidato para aplicações industriais.

Palavras-chaves: myrosinase, Aspergillus sp., sinigrin, glucosinolate, allylisothiocyanate

\section{REFERENCES}

1. Fenwick G.R.; Heaney R.K.; Mullin W.J. Glucosinolates and their breakdown products in food and food plants. CRC Crit. Rev. Food Sci., 18,123-201, 1983.

2. Hartel, F.V.; Brandt, A. Characterization of a Brassica napus myrosinase expressed and sccreted by Pichia pastoris. Protein Expr Purif. 24(2), 221-226, 2002.

3. Maheswari P.N.; Stanley D.W.; Gray J.I. Detoxification of rapeseed production. J. Food Protect., 44, 459-470, 1981.

4. Ohtsuru M.; Hata T. Studies on the activation mechanism of myrosinase by L-ascorbic acid. Agric. Biol. Chem., 37, 2543-2548, 1973.

5. Ohtsuru M.; Tsuruo I.; Hata T. Studies of fungous myrosinase part I: Production, Purification and some characteristics. Agric. Biol. Chem., 33, 1309-1314, 1969.

6. Palop M.L.; Smiths J.P.; Brink B.T. Degradation of sinigrin by Lactobacillus agilis strain R16. Int. J. Food Microbiol., 26, 219229, 1995.

7. Petroski R.J.; Kwolek W.F. Interaction of a fungal thioglucoside glucohydrolase and Cruciferous plant epithiospecifier protein to form 1-cyanoepithioalkanes: Implications of an allosteric mechanism. Phytochem., 24, 213-216, 1985.

8. Poulton, J.E. Cyanogenesis in plants. Plant Physiol. 94, 401-405, 1990.

9. Rakariyatham N.; Sakorn P. Biodegradation of glucosinolates in brown mustard seed meal (Brassica juncea) by Aspergillus sp. NR4201 in liquid and solid-state cultures. Biodegradation., 13, 395 399, 2002.

10. Sakorn P.; Rakariyatham N.; Niamsup H.; Kovitaya P. Sinigrin degradation by Aspergillus sp. NR-4201 in liquid culture. Sci. Asia., 25, 189-194, 1999

11. Sakorn P.; Rakariyatham N.; Niamsup H.; Nongkunsarn P. Rapid detection of myrosinase-production fungi: a plate method based on opaque barium sulphate formation. World J. Microbiol. Biotechnol., 18, 73-74, 2002.

12. Smiths J.P.; Knol W.; Bol J. Glucosinolate degradation by Aspergillus calvatus and Fusarium oxysporum in liquid and solid-state fermentation. Appl. Microbiol. Biotechnol., 38, 696-701, 1993.

13. Wattenberg, L.W.; Hanley, A.B.; Garany, G.; Sparnins, V.L.; Lam, L.K.T.; Fenwick, G.R. Inhibition of carcinogenesis by some minor dietary constituent. In "Diet, Nutrition and Cancer. Proceedings of the Sixteenth International Symposium of the Princess Takamatsu Cancer Research Fund, Tokyo, 1985" (Y. Hayashi et al., eds.), Japan Sci. Soc. Press, Tokyo 1986. p.193-203.

14. Wilkinson, A.P.; Rhodes, M.J.C.; Fenwick, G.R. Determination of myrosinase (thioglucoside glucohydrolase) activity by a spectrophotometric coupled enzyme assay. Anal. Biochem. 139(2), 284-291, 1984. 